\title{
Sulfhydryl oxidation using procedures and experimental conditions commonly used for Treponema pallidum
}

\author{
T J FITZGERALD, R C JOHNSON, AND E T WOLFF \\ From the Department of Medical Microbiology, University of Minnesota Medical School, Minneapolis, \\ Minnesota, USA
}

SUMMARY Certain reducing agents containing sulfhydryl groups are important to the in-vitro survival of Treponema pallidum. Discrepancies occur, however, concerning the agents and the concentrations that are optimal. To clarify some of this confusion, sulfhydryl oxidation was determined using procedures and experimental conditions commonly used for $T$ pallidum. Sulfhydryl oxidation varied according to the type of culture medium, the size of the culture vessels, the volume of the culture medium, and the gaseous environment within the culture vessels, as well as the method of extracting treponemes from infected testicular tissue. Dithiothreitol maintained highly reduced conditions by reducing disulfide groups to sulfhydryl groups. Lastly, the organisms influenced the sulfhydryl concentration by either direct oxidation or specific uptake. The sulfhydryl content was sharply decreased in the presence of viable preparations of $T$ pallidum compared with heated preparations or membrane filtrates of viable preparations.

\section{Introduction}

The presence of sulfhydryl (SH) agents prolongs the in-vitro survival of Treponema pallidum. Brewer ${ }^{1}$ first reported the beneficial effects of sodium thioglycollate on treponemes. Cysteine, glutathione, and thioglycollate were important components of Nelson's basal medium. ${ }^{2}$ Weber ${ }^{3}$ characterised the influences of $\mathrm{SH}$ agents on $\mathrm{T}$ pallidum. Glutathione, cysteine, thioglycollate, mercaptosuccinate, and homocysteine enhanced survival; mercaptoethanol, ethanethiol, and mercaptoethylamine did not affect survival. Metzger and Smogor ${ }^{4}$ reported the effects of various oxidation-reduction potentials on the survival of treponemes. Different combinations and concentrations of glutathione, cysteine, and thioglycollate were used. Optimum survival occurred at $\mathrm{Eh}-230$ to $-240 \mathrm{mV}(\mathrm{pH} \mathrm{7 \cdot 25)}$. Another $\mathrm{SH}$ agent, dithiothreitol, has recently been added to the list of beneficial agents. ${ }^{5}$

In the last five years, there has been a resurgence of interest in attempts to cultivate $T$ pallidum in the presence of tissue culture cells. The diverse findings in published reports on the use of SH agents are

Address for reprints: Dr T J Fitzgerald, Department of Medical Microbiology, 2205 East Fifth Street, Duluth, Minnesota 55812, USA

Received for publication 25 June 1979 shown in table I. In nine separate reports a variety of SH agents at different concentrations was used, whereas in two other reports SH agents were not used.

Reducing agents oxidise in solution. Since the invivo generation time of $T$ pallidum has been estimated to be 30 hours $^{16}$ successful multiplication is likely to require prolonged incubation. Thus, it is important to consider the oxidation of $\mathrm{SH}$ groups during this incubation period. In the modified Nelson's medium used by Weber, ${ }^{3}$ the glutathione and cysteine were $50 \%$ oxidised within four days of incubation. If these agents were partially oxidised before addition of the treponemes, the beneficial effects were sharply decreased. Norris and coworkers ${ }^{17}$ also reported that oxidised $\mathrm{SH}$ agents were far less beneficial, or even detrimental, to treponemal survival.

The purpose of this report is to clarify some of the present confusion regarding $\mathrm{SH}$ agents in tissue culture systems. To this end, SH oxidation was determined using procedures and experimental conditions commonly used for $T$ pallidum.

\section{Materials and methods}

SULFHYDRYL ASSAY

A modified nitroprusside assay ${ }^{18}$ was used to determine low molecular weight $\mathrm{SH}$ compounds. A test 
TABLE I Reducing agents and optimum concentrations for incubation of $T$ pallidum with tissue culture cells

\begin{tabular}{|c|c|c|c|c|}
\hline \multirow[b]{2}{*}{ Report } & \multicolumn{4}{|c|}{ Concentration $(\mathrm{mmol} / \mathrm{l})$} \\
\hline & Glutathione & Cysteine & $\begin{array}{l}\text { Sodium } \\
\text { thioglycollate }\end{array}$ & Dithiothreitol \\
\hline $\begin{array}{l}\text { Fieldsteel et al6 } \\
\text { Fitzgerald et } a / 7\end{array}$ & 0.50 & $0 \cdot 64$ & & $0 \cdot 25$ \\
\hline Fitzgerald et al8 & $4 \cdot 00$ & $1 \cdot 00$ & & \\
\hline Fitzgerald et als & $4 \cdot 00$ & $1 \cdot 00$ & & $1 \cdot 00$ \\
\hline Kiraly and Horvath 11 & $0 \cdot 63$ & $0 \cdot 82$ & $9 \cdot 61$ & \\
\hline Rathlev12 & $1 \cdot 11$ & & & \\
\hline Sandok et al13 & $3 \cdot 91$ & $6 \cdot 61$ & $6 \cdot 14$ & \\
\hline Sandok et al14 & $0 \cdot 40$ & $0 \cdot 68$ & $0 \cdot 64$ & \\
\hline Sandok et al15 & $1 \cdot 95$ & & & \\
\hline
\end{tabular}

sample of $0.5 \mathrm{ml}$ added to $2 \mathrm{ml}$ of water was mixed with $1 \mathrm{ml}$ of $13 \%(\mathrm{u} / \mathrm{v})$ sulfosalicylic acid. After incubation for 10 minutes in a water bath at $37^{\circ} \mathrm{C}$ the samples were centrifuged for 10 minutes at $1000 \times g$. A volume of $1.5 \mathrm{ml}$ of the supernatant was removed and $1 \mathrm{ml}$ of $\mathrm{K}_{2} \mathrm{CO}_{2} \cdot \mathrm{NaCn}$ and $1 \mathrm{ml}$ of sodium nitroprusside were added. After six minutes at $22^{\circ} \mathrm{C}$, the percentage transmittance was read at $525 \mathrm{mmol} / \mathrm{l}$ using a Zeiss PM Q11 spectrophotometer. This procedure was highly reproducible; similar readings were recorded within triplicate samples and within control preparations in different experiments.

\section{SH AGENTS}

Crystalline-reduced glutathione, cysteine, and dithiothreitol were obtained from Sigma. These reagents were stored in a desiccator at $4^{\circ} \mathrm{C}$ in an atmosphere of $95 \%$ nitrogen and $5 \%$ carbon dioxide. Fresh solutions were prepared on the day of the experiment.

\section{GASEOUS ENVIRONMENTS}

To test various gaseous environments, experiments were performed in 10-litre desiccator jars that were evacuated and flushed five times with the appropriate gas mixture. One mixture contained $95 \%$ nitrogen and $5 \%$ carbon dioxide; it is referred to as $0 \%$ oxygen. Another mixture contained $2 \cdot 5 \%$ oxygen, $92.5 \%$ nitrogen, and $5 \%$ carbon dioxide; it is referred to as $\mathbf{2 . 5 \%}$ oxygen. These two commercially prepared gas mixtures were obtained from and analysed by Ohio Medical Supply (Cleveland, Ohio).

RABBITS

Adult Dutch Belt rabbits weighing approximately $1 \cdot 81-2 \cdot 72 \mathrm{~kg}$ were used. Animals were screened for Treponema paraluis cuniculi infection by physical examination and by serological testing with the rapid plasma reagin circle card test (Hynson, Westcott, and Dunning, Baltimore, Maryland). Rabbits were maintained at $19-20^{\circ} \mathrm{C}$ and given antibiotic-free food and water in unrestricted quantities.

\section{$T$ PALLIDUM}

The Nichols strain of $T$ pallidum was passaged intratesticularly. Each testis received $1 \times 10^{7}$ to $3 \times 10^{7}$ treponemes. Daily intramuscular injections of cortisone acetate (Merck Sharp and Dohme, West Point, Pennsylvania) at $6 \mathrm{mg} / \mathrm{kg}$ were given three days after inoculation of testes. After a satisfactory orchitis had developed, usually within 9-11 days, the animals were killed by intracardiac injection of sodium pentobarbital. Testes were removed, rinsed in physiological saline, and placed in tissue culture medium. The basal tissue culture medium contained Eagle's minimal essential medium (MEM) with Hank's balanced salts, $2 \times$ amino acids, $2 \times$ vitamins, and $4 \mathrm{mmol} / 1 \mathrm{NaHCO}_{3}$. It was buffered with $30 \mathrm{mmol} / 1 \mathrm{~N}-2$-hydroxyethyl-piperazine- $\mathrm{N}-2$ ethane-sulfonic acid. A supplement of $10 \%(\mathrm{v} / \mathrm{v})$ heat-inactivated $\left(56^{\circ} \mathrm{C}, 30\right.$ minutes) fetal bovine serum (FBS) (Reheis Chemical Co, Kankakee, Illinois) was added. This medium is referred to as Eagle's MEM with 10\% FBS. The tissue was sliced and extracted for 10-20 minutes at room temperature under aerobic conditions without shaking. The suspension was centrifuged at $1000 \times g$ for seven minutes at $22^{\circ} \mathrm{C}$ to sediment particulate matter, and the supernatant containing the organisms was decanted. For experiments requiring concentrated suspensions of organisms, this supernatant was then centrifuged at $12000 \times g$ for 30 minutes at $4^{\circ} \mathrm{C}$. The pelleted treponemes were resuspended in smaller volumes of the supernatant.

\section{SOURCE AND MAINTENANCE OF CULTURED} CELLS

Primary cultures of normal rabbit testis were established as previously described. ${ }^{7}$ The basal medium for growth of the cultured cells was identical to that used for the extraction of $T$ pallidum.

\section{Results}

A standard curve was established using different concentrations of glutathione (GSH) and cysteine 


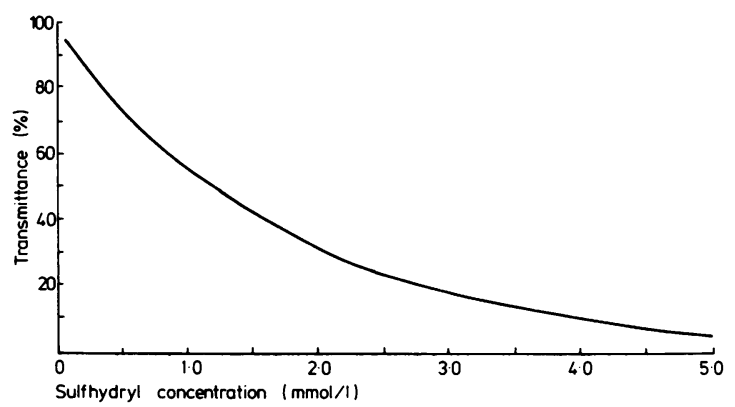

FIGURE Standard curve for relating percentage

transmittance in the nitroprusside reaction to sulfhydryl (SH) concentration.

(cySH) in saline. Previous studies with tissue culture cells had indicated optimum GSH and cySH concentrations of $4 \mathrm{mmol} / 1$ and $1 \mathrm{mmol} / 1$ respectively for maintaining survival of $T$ pallidum. ${ }^{5}$ To establish a standard curve, GSH was tested at $0.33,0.98,1.63$, $2 \cdot 61,3 \cdot 26,3 \cdot 91$, and $4 \cdot 89 \mathrm{mmol} / \mathrm{l}$; cySH was tested at $0.08,0.83,1.65$, and $2.48 \mathrm{mmol} / \mathrm{l}$. A third preparation contained GSH and cySH at a $4: 1$ ratio at final concentrations of $0 \cdot 10,0 \cdot 37,1 \cdot 13,1 \cdot 88$, $2 \cdot 62,3 \cdot 00,3 \cdot 76,4 \cdot 88$, and $5 \cdot 00 \mathrm{mmol} / 1 \mathrm{SH}$. The SH moiety of GSH is cySH. Thus, the nitroprusside assay of the three preparations measures cySH. When the data were plotted on a graph (figure), each of the three curves closely overlapped. To determine SH concentration within test samples, the percentage transmittance was compared to the standard curve.

Standard curves were also established with the SH agents dissolved in basal tissue culture medium instead of saline. Identical data were recorded. Only one difference was apparent. When standing, the SH agents oxidised more quickly in basal medium; oxidation even occurred at $-20^{\circ} \mathrm{C}$. Thus, in all experiments crystalline GSH and cySH were dissolved in the appropriate medium just before the experiment was begun.

DIFFERENT TREPONEMAL MEDIA

SH oxidation in different treponemal suspending media was examined (table II). GSH (4 mmol/l) and
cySH $(1 \mathrm{mmol} / \mathrm{l})$ were added to Eagle's MEM, McCoy's medium, $50 \%$ normal rabbit serum plus $50 \%$ saline, and $50 \%$ FBS plus $50 \%$ saline. Incubation was performed in air at $36^{\circ} \mathrm{C}$ in $50-\mathrm{ml}$ screw-cap test tubes containing $20 \mathrm{ml}$ of medium.

The most rapid oxidation occurred in rabbit serum (table II). Within four hours, its SH content had decreased to $2 \mathrm{mmol} / \mathrm{l}$ compared with $3.4 \mathrm{mmol} / \mathrm{l}$ for the other three media. Slowest oxidation occurred in McCoy's medium. After 24 hours, pronounced differences were observed. The SH concentration had decreased to $0.6 \mathrm{mmol} / \mathrm{l}$ in rabbit serum, to $1.3 \mathrm{mmol} / \mathrm{l}$ in Eagle's MEM, to $1.6 \mathrm{mmol} / \mathrm{l}$ in FBS, and to $2.2 \mathrm{mmol} / 1$ in McCoy's medium. With continued incubation, $\mathrm{SH}$ oxidation slowed considerably. After 170 hours, the SH concentration was $0.7 \mathrm{mmol} / \mathrm{l}$ in rabbit serum, $0.9 \mathrm{mmol} / 1$ in FBS, and $1.3 \mathrm{mmol} / 1$ in both Eagle's MEM and McCoy's medium.

\section{FLUID SURFACE AREA}

SH oxidation is related to the amount of fluid surface area in direct contact with the atmosphere. To this end, $15 \mathrm{ml}$ of medium was added to a 600 -ml bottle, a T-30 culture flask (75-ml volume), and a $15-\mathrm{ml}$ screw-cap test tube. The medium contained GSH $(4 \mathrm{mmol} / \mathrm{l})$ and cySH $(1 \mathrm{mmol} / \mathrm{l})$ in Eagle's MEM with $10 \%$ FBS. These vessels were incubated in air at $36^{\circ} \mathrm{C}$. Owing to the smaller area interface between air and medium, slowest $\mathrm{SH}$ oxidation occurred in the test tube (table III). After seven hours, the SH

TABLE III Oxidation of SH agents in different containers*

\begin{tabular}{llll}
\hline \multirow{4}{*}{ Time $(h)$} & \multicolumn{3}{l}{$S H$ concentration $(\mathrm{mmol} / \mathrm{l})$} \\
\cline { 2 - 4 } & $\begin{array}{l}600-\mathrm{ml} \\
\text { bottle }\end{array}$ & $\begin{array}{l}T-30 \\
\text { flask }\end{array}$ & $\begin{array}{l}15-\mathrm{ml} \\
\text { test tube }\end{array}$ \\
\hline 0 & 5.0 & 4.9 & 5.0 \\
7 & 1.6 & 2.4 & 3.6 \\
19 & 1.3 & 1.3 & 3.2 \\
25 & 1.3 & 1.3 & 2.6 \\
44 & 1.4 & 1.4 & 2.1 \\
66 & 1.4 & 1.4 & 1.6 \\
\hline
\end{tabular}

*Air incubation of vessels containing $15 \mathrm{ml}$ of Eagle's MEM with $10 \%$ FBS

TABLE II Oxidation of SH agents in different treponemal culture media*

\begin{tabular}{cllll}
\hline \multirow{2}{*}{ Time $(h)$} & \multicolumn{2}{l}{ SH concentration (mmol/l) in different media } \\
\cline { 2 - 5 } & NRS/saline & FBS/saline & Eagle's MEM & McCoy's \\
\hline 0 & $5 \cdot 0$ & $5 \cdot 0$ & $5 \cdot 0$ & $4 \cdot 9$ \\
4 & $2 \cdot 0$ & $3 \cdot 4$ & $3 \cdot 4$ & $3 \cdot 4$ \\
12 & $1 \cdot 7$ & $2 \cdot 5$ & $1 \cdot 3$ & $3 \cdot 0$ \\
24 & $0 \cdot 6$ & $1 \cdot 6$ & $1 \cdot 0$ & $1 \cdot 2$ \\
48 & $0 \cdot 5$ & $1 \cdot 0$ & $1 \cdot 3$ & $1 \cdot 1$ \\
170 & $0 \cdot 7$ & 0.9 & $1 \cdot 3$ \\
\hline
\end{tabular}

*Air incubation in 50-ml screw-cap test tubes containing $20 \mathrm{ml}$ of medium

NRS $=$ normal rabbit serum

FBS $=$ fetal bovine serum 
TABLE IV Oxidation of SH agents in different volumes*

\begin{tabular}{lll}
\hline & \multicolumn{2}{l}{$S H$ concentration $(\mathrm{mmol} / \mathrm{l})$} \\
\cline { 2 - 3 } Time $(h)$ & $\begin{array}{l}5-\mathrm{ml} \\
\text { volume }\end{array}$ & $\begin{array}{l}15-\mathrm{ml} \\
\text { volume }\end{array}$ \\
\hline 0 & $4 \cdot 9$ & 4.9 \\
5 & $3 \cdot 7$ & $3 \cdot 8$ \\
10 & $3 \cdot 2$ & 3.7 \\
20 & $2 \cdot 2$ & 3.3 \\
48 & 0.8 & 2.5 \\
\hline
\end{tabular}

*Air incubation of 15-ml screw-cap test tubes containing Eagle's MEM with $10 \%$ FBS

content within the $600-\mathrm{ml}$ bottle was $1.6 \mathrm{mmol} / \mathrm{l}$ compared with $2.4 \mathrm{mmol} / \mathrm{l}$ for the T-30 vessel and $3.6 \mathrm{mmol} / \mathrm{l}$ for the test tube. After 19 hours, SH concentration in the large bottle and the T-30 flask was $1.3 \mathrm{mmol} / \mathrm{l}$ compared with $3.2 \mathrm{mmol} / \mathrm{l}$ in the test tube. A plateau of SH oxidation was detected with continued incubation. This plateau was reached within 19 hours in the bottle and T-30 vessel and within 66 hours in the test tube.

\section{DIFFERENT VOLUMES OF MEDIA}

SH oxidation should also be related to the volume of medium within the culture vessels. In the next set of experiments, $5 \mathrm{ml}$ and $15 \mathrm{ml}$ of medium were added to $15-\mathrm{ml} \mathrm{screw-cap}$ test tubes. The medium contained GSH (4 mmol/l) and cySH $(1 \mathrm{mmol} / \mathrm{l})$ in Eagle's MEM with $10 \%$ FBS. The tubes were incubated in air at $36^{\circ} \mathrm{C}$. Oxidation of $\mathrm{SH}$ was much faster in the smaller volume (table IV). After 20 hours, the 5-ml sample contained $2 \cdot 2 \mathrm{mmol} / \mathrm{l} \mathrm{SH}$ compared with $3.3 \mathrm{mmol} / \mathrm{l}$ in the $15-\mathrm{ml}$ sample. After $\mathbf{4 8}$ hours, the $15-\mathrm{ml}$ sample contained three times as much $\mathrm{SH}$ as the 5 - $\mathrm{ml} \mathrm{sample}(2.5 \mathrm{mmol} / \mathrm{l}$ and $0.8 \mathrm{mmol} / \mathrm{l} \mathrm{respec-}$ tively).

\section{GASEOUS ENVIRONMENT}

In previous tissue culture experiments, treponemes were incubated in different gaseous environments. ${ }^{5}$ Experiments were performed to assess $\mathrm{SH}$ oxidation within these environments. GSH $(4 \mathrm{mmol} / \mathrm{l})$ and

TABLE $\mathrm{v}$ Oxidation of $\mathrm{SH}$ agents in different gaseous environments*

\begin{tabular}{clll}
\hline & \multicolumn{3}{l}{$S H$ concentration (mmol/l) } \\
\cline { 2 - 4 } Time $(h)$ & Air & $2.5 \%$ Oxygen & $0 \%$ Oxygen \\
\hline 0 & 4.9 & 5.0 & 4.9 \\
5 & 2.2 & 3.6 & 4.7 \\
20 & 0.9 & 2.6 & 4.7 \\
48 & 0.9 & 1.7 & 2.7 \\
72 & 0.9 & 1.3 & 2.3 \\
96 & 0.9 & 1.0 & 2.3 \\
170 & 0.9 & 0.9 & 2.0 \\
\hline
\end{tabular}

*Incubation in T-30 culture vessels containing $7 \mathrm{ml}$ of Eagle's MEM with $10 \%$ FBS
cySH $(1 \mathrm{mmol} / \mathrm{l})$ in Eagle's MEM with $10 \%$ FBS were exposed to air (approximately $21 \%$ oxygen), $2.5 \%$ oxygen, or $0 \%$ oxygen. T-30 culture vessels containing $7 \mathrm{ml}$ of medium were incubated with loose-fitting metal caps at $36^{\circ} \mathrm{C}$.

Oxidation of SH was very rapid in air, minimal in $0 \%$ oxygen, and intermediate in $2.5 \%$ oxygen (table V). After five hours, $2 \cdot 2 \mathrm{mmol} / \mathrm{l} \mathrm{SH}$ remained in the medium exposed to air compared with $3.6 \mathrm{mmol} / \mathrm{l}$ in $2.5 \%$ oxygen and $4.7 \mathrm{mmol} / \mathrm{l}$ in $0 \%$ oxygen. Pronounced differences were apparent after 20 hours. The sample in air contained $0.9 \mathrm{mmol} / 1 \mathrm{SH}$ compared with $2.6 \mathrm{mmol} / \mathrm{l} \mathrm{SH}$ in $2.5 \%$ oxygen and $4.7 \mathrm{mmol} / 1 \mathrm{SH}$ in $0 \%$ oxygen. SH oxidation decreased to its lowest level after 20 hours in air compared with 170 hours in the other two environments.

\section{ADDITION OF DITHIOTHREITOL}

Previous studies had indicated that dithiothreitol (DTT) at $1-2 \mathrm{mmol} / \mathrm{l}$ prolonged treponemal survival. ${ }^{5}$ The beneficial effect of this reducing agent might be related to its ability to reduce disulfide (SS) groups to $\mathrm{SH}$ groups. ${ }^{19}$ To test this possibility, various concentrations of DTT $(0 \cdot 1-2 \mathrm{mmol} / \mathrm{l})$ were added to Eagle's MEM with 10\% FBS containing GSH $(4 \mathrm{mmol} / \mathrm{l})$ and cySH $(1 \mathrm{mmol} / \mathrm{l})$. Incubation was performed in air in 50-ml screw-cap test tubes containing $15 \mathrm{ml}$ of medium. Far less SH oxidation was observed in the presence of 1 and $2 \mathrm{mmol} / 1$ DTT. SH oxidation was marginally decreased at $0.5 \mathrm{mmol} / \mathrm{I}$ DTT. No effects on SH oxidation were detected with DTT at $0.1 \mathrm{mmol} / \mathrm{l}$. DTT alone was not reactive in this assay. Apparently, the sulfosalicylic acid precipitated this compound.

\section{SEQUENTIAL ADDITIONS OF DTT}

Treponemal survival in the presence of tissue culture cells is enhanced by the addition of $1 \mathrm{mmol} / \mathrm{l} \mathrm{DTT}$ every 24 hours. $^{5}$ Experiments were undertaken to assess $\mathrm{SH}$ oxidation in the absence of treponemes. A volume of $15 \mathrm{ml}$ of Eagle's MEM with 10\% FBS with

TABLE VI Delay of SH oxidation by sequential addition of dithiothreitol (DTT)*

\begin{tabular}{|c|c|c|c|c|c|}
\hline \multirow[b]{2}{*}{ Time (h) } & \multicolumn{5}{|c|}{ SH concentration $(\mathrm{mmol} / \mathrm{l})$} \\
\hline & Flask I & Flask 2 & Flask 3 & Flask 4 & Flask 5 \\
\hline $\begin{array}{r}0 \\
20 \\
44 \\
66 \\
93 \\
126\end{array}$ & $\begin{array}{l}4 \cdot 9 \\
3 \cdot 2 \\
2 \cdot 0 \\
1 \cdot 6 \\
1 \cdot 6 \\
1 \cdot 2\end{array}$ & $\begin{array}{l}5 \cdot 0+ \\
4 \cdot 7 \\
2 \cdot 8 \\
2 \cdot 2 \\
2 \cdot 2 \\
1 \cdot 8\end{array}$ & $\begin{array}{l}5 \cdot 0+ \\
4 \cdot 6+ \\
4 \cdot 6 \\
2 \cdot 7 \\
2 \cdot 7 \\
1 \cdot 9\end{array}$ & $\begin{array}{l}5 \cdot 0+ \\
4 \cdot 7 \dagger \\
4 \cdot 6 \dagger \\
4 \cdot 5 \\
4 \cdot 5 \\
2 \cdot 5\end{array}$ & $\begin{array}{l}5 \cdot 0 \dagger \\
4 \cdot 7 \dagger \\
4 \cdot 6 \dagger \\
4 \cdot 6 \dagger \\
4 \cdot 6 \\
3 \cdot 2\end{array}$ \\
\hline
\end{tabular}

*Air incubation in T-30 culture vessels containing $15 \mathrm{ml}$ of Eagle's MEM with $10 \%$ FBS and cultured rabbit testis cells tAdded $1 \mathrm{mmol} / \mathrm{I}$ DTT 
GSH $(4 \mathrm{mmol} / \mathrm{l})$ and cySH $(1 \mathrm{mmol} / \mathrm{l})$ was incubated in $2.5 \%$ oxygen in $\mathrm{T}-30$ culture vessels containing confluent monolayers of normal rabbit testis cells. DTT at $1 \mathrm{mmol} / \mathrm{l}$ was added to the various flasks at the times indicated in table VI. Assays for SH groups were performed immediately after the addition of DTT (table VI).

The periodic addition of DTT maintained reduced conditions for extended periods. Fastest SH oxidation occurred in flask 1; slowest $\mathrm{SH}$ oxidation occurred in flask 5 . The length of incubation required for each flask to decrease to approximately $3 \cdot 2 \mathrm{mmol} / \mathrm{l} \mathrm{SH}$ was noteworthy: flask 1,20 hours; flask 2, 20-44 hours; flask 3, 44-66 hours; flask 4, 93-126 hours; and flask 5, 126 hours.

Two comments about DTT are pertinent. Firstly, the addition of this agent had an immediate effect on SH concentration. For example, samples that contained $1 \cdot 2 \mathrm{mmol} / \mathrm{l} \mathrm{SH}$ increased to $2 \cdot 1 \mathrm{mmol} / \mathrm{l}$ SH 30 minutes after addition of DTT. This reduction of SS may have been quicker but the nitroprusside assay required at least 26 minutes to complete. Secondly, the storage of DTT at $-20^{\circ} \mathrm{C}$ did not adversely influence the effectiveness of DTT in reducing SS groups. After storage for two months this agent remained as potent as freshly prepared DTT.

\section{TISSUE EXTRACTION PROCEDURES}

Experiments were then performed to investigate SH oxidation using different extraction procedures for harvesting treponemes from testicular tissue. Two infected testes were sliced centrally and equivalent amounts of tissue were placed in different Petri dishes. In one dish, the tissue was carefully sliced with a sharp scalpel. In a second dish, the tissue was cut with scissors and minced with forceps. The tissue in the third dish was cut with scissors and finely ground for 5 minutes with a pestle and mortar. The culture medium contained Eagle's MEM with $10 \%$ FBS with GSH $(4 \mathrm{mmol} / \mathrm{l})$ and cySH $(1 \mathrm{mmol} / \mathrm{l})$. Treponemes were extracted for 30 minutes in air. Each preparation was centrifuged at $1000 \times g$ for seven minutes to remove particulate matter. A volume of $5 \mathrm{ml}$ was then placed into $\mathrm{T}-15$ culture vessels without cultured cells and incubated in air. At various intervals, samples were removed and assessed for treponemal motility and for SH content. As a control, culture medium was used that was not exposed to tissue extraction.

The data from the four experiments are presented in table VII. The fastest oxidation was detected in the sample that was finely ground with pestle and mortar. The slowest oxidation, other than the control, was detected in the sliced tissue. After 11 hours, the sliced tissue sample contained $2 \cdot 2 \mathrm{mmol} / \mathrm{l}$
TABLE VII Oxidation of SH groups as a function of tissue extraction procedures *

\begin{tabular}{lllll}
\hline \multicolumn{5}{c}{ SH concentration $(\mathrm{mmol} / \mathrm{l})$} \\
\cline { 2 - 5 } Time $(\mathrm{h})$ & Control & Sliced & $\begin{array}{l}\text { Cut and } \\
\text { minced }\end{array}$ & $\begin{array}{l}\text { Finely } \\
\text { ground }\end{array}$ \\
\hline 2 & $4 \cdot 0$ & $4 \cdot 0$ & 4.0 & 4.0 \\
5 & 3.9 & 3.3 & 2.4 & 2.4 \\
11 & $3 \cdot 3$ & 2.2 & 1.1 & 0.8 \\
21 & 1.5 & 1.3 & 0.7 & 0.5 \\
47 & 0.8 & 0.8 & 0.5 & 0.2 \\
\hline
\end{tabular}

*Air incubation in T-15 culture vessels containing $5 \mathrm{ml}$ of Eagle's MEM with $10 \%$ FBS

SH compared with $1.1 \mathrm{mmol} / \mathrm{l} \mathrm{SH}$ in the cut and minced sample and $0.8 \mathrm{mmol} / \mathrm{l} \mathrm{SH}$ in the finely ground sample. In addition, treponemal motility was apparently affected by the extraction procedure. Best motility occurred in the tissue samples that were sliced; poorest motility occurred in the finely ground samples.

\section{OXIDATION/UPTAKE BY T PALLIDUM}

To assess the role of $T$ pallidum in decreasing the $\mathrm{SH}$ content within the culture medium treponemes were extracted from infected tissue in a volume of $55 \mathrm{ml}$ of Eagle's MEM with 10\% FBS containing GSH (4 $\mathrm{mmol} / \mathrm{l})$ and cySH $(1 \mathrm{mmol} / \mathrm{l})$. After extraction and slow-speed centrifugation to remove particulate matter the organisms were pelleted by high-speed centrifugation. The concentrated treponemes were resuspended in $10 \mathrm{ml}$ of the supernatant at approximately $1 \times 10^{8}$ treponemes $/ \mathrm{ml}$. This treponemal suspension was equally divided; one-half was heated at $50^{\circ} \mathrm{C}$ for five minutes to immobilise the organisms. Four T-15 flasks with confluent monolayers of normal rabbit testis cells were used. Viable treponemes were added to one, heated treponemes were added to another, and the supernatant from the high-speed centrifugation that was membranefiltered $(0 \cdot 2 \mu$ pore size) was added to another. The control flask contained culture medium not exposed to testicular extraction. Incubation was performed in $2.5 \%$ oxygen. To maintain treponemal survival, DTT was added periodically to each of the four flasks as indicated in table VIII. The data represent the mean of four separate experiments.

The SH content remaining in the flasks containing heated treponemes, high-speed supernatant, and control medium was similar at each time period. The viable treponemal preparation either utilised or was responsible for oxidation of SH groups. This was apparent after incubation for 90 hours. At this time, the viable preparation contained $1.8 \mathrm{mmol} / 1 \mathrm{SH}$ compared with $2 \cdot 7-3.0$ for the other three preparations. After 138 hours, the viable preparation contained only one-third to one-half as much $\mathrm{SH}$ as 
TABLE VIII Oxidation or uptake of SH agents by $T$ pallidum or both*

\begin{tabular}{|c|c|c|c|c|c|}
\hline \multirow[b]{2}{*}{ Time (h) } & \multicolumn{4}{|c|}{ SH concentration ( $\mathrm{mmol} / \mathrm{l})$} & \multirow{2}{*}{$\begin{array}{l}\% \text { Motility } \\
\text { Viable } \\
\text { treponemes }\end{array}$} \\
\hline & $\begin{array}{l}\text { Control } \\
\text { suspending } \\
\text { medium }\end{array}$ & $\begin{array}{l}\text { Heated } \\
\text { treponemes }\end{array}$ & $\begin{array}{l}\text { Supernate } \\
\text { without } \\
\text { treponemes }\end{array}$ & $\begin{array}{l}\text { Viable } \\
\text { treponemes }\end{array}$ & \\
\hline $\begin{array}{c}0 \\
18 \dagger \\
50 \dagger \\
66 \dagger \\
90 \dagger \\
114 \dagger \\
138+\end{array}$ & $\begin{array}{l}5 \cdot 0 \\
3 \cdot 7 \\
3 \cdot 2 \\
3 \cdot 7 \\
3 \cdot 0 \\
2 \cdot 9 \\
2 \cdot 0\end{array}$ & $\begin{array}{l}4 \cdot 9 \\
3 \cdot 5 \\
3 \cdot 0 \\
3 \cdot 7 \\
2 \cdot 7 \\
2 \cdot 5 \\
1 \cdot 5\end{array}$ & $\begin{array}{l}4 \cdot 9 \\
3 \cdot 5 \\
3 \cdot 0 \\
3 \cdot 7 \\
2 \cdot 8 \\
2 \cdot 5 \\
1 \cdot 5\end{array}$ & $\begin{array}{l}4 \cdot 9 \\
3 \cdot 5 \\
3 \cdot 0 \\
3 \cdot 5 \\
1 \cdot 8 \\
1 \cdot 3 \\
0 \cdot 7\end{array}$ & $\begin{array}{r}98 \\
98 \\
90 \\
72 \\
16 \\
8 \\
0\end{array}$ \\
\hline
\end{tabular}

*Incubation in 2.5\% oxygen in T-15 culture vessels containing $5 \mathrm{ml}$ of Eagle's MEM with $10 \%$ FBS and cultured rabbit testis cells. †Added $1 \mathrm{mmol} / \mathrm{l}$ DTT

the other three preparations $(0 \cdot 7 \mathrm{mmol} / \mathrm{l}$ compared with $1 \cdot 5-2 \cdot 0 \mathrm{mmol} / \mathrm{l})$. Motile treponemes in the viable preparation were observed for 114 hours.

\section{Discussion}

It is well established that certain SH agents are vital to prolong the in-vitro survival of $T$ pallidum. As shown in table I, however, differences exist between laboratories concerning the agents and the optimum concentrations. The purpose of this paper was to demonstrate the wide variation in SH content within different experimental systems. Oxidation to SS groups was related to the size of the culture vessels, the volume of fluid in the vessels, the gaseous environment within the vessels, and the treponemal suspending medium. SH oxidation was also dependent on the method of extracting treponemes from infected tissue. These observations emphasise the importance of clearly defining experimental conditions. For example, a specific concentration of glutathione may be beneficial to treponemal survival when incubation is performed in 5-ml test tubes containing $3 \mathrm{ml}$ of medium. This same concentration of glutathione, however, will probably not be optimal if the $3 \mathrm{ml}$ of treponemes are in a larger test tube or a T-30 flask. Furthermore, concentrations of SH agents that are optimal for treponemes in Nelson's medium may not be optimal for treponemes in Eagle's MEM.

Two examples within our laboratory illustrate the problems associated with SH content using different experimental conditions. When treponemes are incubated in a T-30 culture vessel and in a SykesMoore chamber, similar periods of survival occur in each vessel (5-7 days). With the T-30 vessel, but not the chamber, it is necessary to add DTT daily. This may reflect faster SH oxidation in the larger vessel. A second example concerns different incubation systems. In a small test tube containing $1 \mathrm{ml}$ of treponemes, better survival occurs in $3 \%$ oxygen in the presence of DTT; poorer survival occurs with the combination of DTT, GSH, and cySH. ${ }^{17}$ In a T-30 vessel containing cultured cells in $2.5 \%$ oxygen this was not observed; best survival occurred with the combination of DTT, GSH, and cySH.

The influences of DTT on SH oxidation were noteworthy. This agent is an important addition to the tissue culture-T pallidum system. The initial report of the beneficial effects of DTT indicated that the minimum concentration for prolonging treponemal survival was approximately $1 \mathrm{mmol} / 1 .{ }^{5}$ The data in this report agree with this observation. DTT at $1 \mathrm{mmol} / \mathrm{l}$ effectively slowed the oxidation of $\mathrm{SH}$ groups. Previous observations had also demonstrated the beneficial influences of daily addition of DTT to the treponeme-cell culture system. ${ }^{5}$ This procedure resulted in a significant delay in $\mathrm{SH}$ oxidation (table VI).

A major advantage of DTT is its stability. Solutions of glutathione and cysteine rapidly oxidise in air; DTT does not. ${ }^{19}$ Furthermore, DTT is oxidised in the process of reducing other SS groups, and oxidised DTT does not further influence the system. ${ }^{19}$ The opposite applies to glutathione and cysteine. When these two agents oxidise, they enhance the chemical reaction favouring SS formation. ${ }^{20-23}$ This may be one of the reasons why Weber $^{3}$ failed to show that sequential additions of cysteine had beneficial effects on treponemal survival.

The precise role of $\mathrm{SH}$ agents in prolonging treponemal survival is unknown. Two possibilities have been suggested: $:^{2-4}$ (a) $\mathrm{SH}$ agents poise the redox potential of the suspending medium, partially neutralising oxygen toxicity; and (b) $T$ pallidum requires certain SH agents for active metabolic functioning.

In determining optimum concentrations of $\mathrm{SH}$ agents, it is important to consider the oxygen- $T$ pallidum interaction. Previously, this organism was considered a strict anaerobe. In an important 
finding, Cox and Barber ${ }^{24}$ demonstrated that $T$ pallidum (Nichols strain) takes up oxygen, suggesting an aerobic nature. Baseman and co-workers ${ }^{25}$ reported maximum retention of treponemal survival in $10-20 \%$ oxygen. Fitzgerald et $a l,{ }^{5}$ Fieldsteel et $a l,{ }^{6}$ Norris et $a l,{ }^{17}$ and Sandok et $a l^{15}$ reported maximum treponemal survival in relatively low concentrations of oxygen (less than $5 \%$ ). SH content, affected by differing experimental conditions, may be the reason for these discrepancies. Two comments are pertinent; firstly, the concentration of dissolved oxygen within the culture medium is related to the concentration of reducing agents. Molecular oxygen reacts with SH groups to yield SS groups and water, thereby decreasing the amount of dissolved oxygen present. ${ }^{22} 2326$ Secondly, the toxicity of oxygen to micro-organisms appears to be mediated through free radicals. ${ }^{27} \mathrm{SH}$ groups are able to scavenge free radicals. ${ }^{22} 2328$ In the process of interacting with the $\mathrm{SH}$ moiety, the free radical is neutralised, resulting in SS formation. Thus, SH agents conceivably minimise oxygen toxicity by inactivating free radicals. Incubation in the presence of increasing concentrations of oxygen would probably require increasing concentrations of SH agents to counteract oxygen toxicity.

In support of this, Norris and co-workers ${ }^{17}$ recently examined the survival of $T$ pallidum (Nichols strain) in $21 \%, 3 \%$, and $0 \%$ oxygen in the presence and absence of $\mathrm{SH}$ agents. Poor survival was observed under aerobic conditions ( $21 \%$ oxygen) with and without SH agents. Interestingly, directly opposing effects were apparent in the presence of two lower oxygen concentrations. Maximum treponemal survival occurred in $0 \%$ oxygen without SH agents. In contrast, with dithiothreitol the treponemes survived for much longer periods in $3 \%$ oxygen than in $0 \%$ oxygen.

Besides control of oxygen toxicity, SH groups may be critical to metabolic functioning of $T$ pallidum. Weber ${ }^{3}$ examined the effects of different $\mathrm{SH}$ agents on treponemal survival. Some were beneficial and some were not. Since the ineffective agents also lower redox potential, he stated that control of redox potential could not be the sole function of these agents. In the present report the data in table VIII indicate the direct interaction of $\mathrm{SH}$ agents with $T$ pallidum. SH content in viable treponemal preparations was sharply decreased compared with nonviable preparations or with membrane filtrates of viable preparations. Viable $T$ pallidum either oxidises or takes up the SH agents, thereby decreasing their concentration in the suspending medium.

Thus, it appears as if successful in-vitro multiplication will require a delicate balance provided by specific concentrations of various $\mathrm{SH}$ agents. These concentrations will have to be carefully balanced and maintained during prolongeci periods of in-vitro incubation.

Funds for this study were provided by Public Health Service grants AI-08124 and AI-12978 from the National Institutes of Health, Allergy and Infectious Diseases Branch.

\section{References}

1. Brewer JH. Clear liquid mediums for "aerobic" cultivation of anaerobes. J Amer Med Assoc 1940; 115:598-600.

2. Nelson RA. Factors affecting the survival of Treponema pallidum in vitro. Amer $J$ Epidemiol 1948;48: 120-32.

3. Weber MM. Factors influencing the in-vitro survival of Treponema pallidum. Amer J Epidemiol 1960; 71:401-17.

4. Metzger M, Smogor W. Study of the effect of $\mathrm{pH}$ and $\mathrm{Eh}$ values of the Nelson-Diesendruck medium on the survival of virulent Treponema pallidum. Arch Immunol Ther Exp 1966; 14:445-53.

5. Fitzgerald TJ, Johnson RC, Sykes JA, Miller JN. Interaction of Treponema pallidum (Nichols strain) with cultured mammalian cells: effects of oxygen, reducing agents, serum supplements, and different cell types. Infect Immun 1977; 15:444-52.

6. Fieldsteel HA, Becker FA, Stout JG. Prolonged survival of virulent Treponema pallidum (Nichols strain) in cell-free and tissue culture systems. Infect Immun 1977; 18: 173-82.

7. Fitzgerald TJ, Miller JN, Sykes JA. Treponema pallidum (Nichols strain) in tissue cultures: cellular attachment, entry, and survival. Infect Immun 1975; 11:1133-40.

8. Fitzgerald TJ, Johnson RC, Miller JN, Sykes JA. Characterization of the attachment of Treponema pallidum (Nichols strain) to cultured mammalian cells and the potential relationship of attachment to pathogenicity. Infect Immun 1977; 18:467-78.

9. Hayes, NS, Muse KE, Collier AM, Baseman JB. Parasitism by virulent Treponema pallidum of host-cell surfaces. Infect Immun 1977; 17: 174-86.

10. Jones RH, Finn MA, Thomas JJ, Folger C. Growth and subculture of pathogenic $T$ pallidum (Nichols strain) in BHK-21 cultured tissue cells. $\mathrm{Br} J$ Vener Dis 1976;52:18-23.

11. Kiraly $\mathrm{K}$, Horvath I. Survival of $T$ pallidum under microaerophilic conditions in cell and tissue cultures. Zentralbl Bakteriol (Orig A) 1976; 235:500-5.

12. Rathlev T. Investigations of in-vitro.survival and virulence of Treponema pallidum under aerobiosis. Br J Vener Dis 1975; 51:296-300.

13. Sandok PL, Jenkin HM, Graves SR, Knight ST. Retention of motility of Treponema pallidum (Nichols virulent strain) in an anaerobic cell culture system and in a cell-free system. $J$ Clin Microbiol 1976; 3:72-4.

14. Sandok PL, Knight ST, Jenkin HM. Examination of various cell culture techniques for coincubation of virulent Treponema pallidum (Nichols strain) under anaerobic conditions. $J$ Clin Microbiol 1976; 4: 360-71.

15. Sandok PL, Jenkin HM, Matthews HM, Roberts MS. Unsustained multiplication of Treponema pallidum (Nichols virulent strain) in vitro in the presence of oxygen. Infect Immun 1978; 19:421-9.

16. Magnuson HJ, Eagle H, Fleischmann R. The minimal infectious dose of Spirochaeta pallida (Nichols strain) and a consideration of its rate of multiplication in vivo. Amer J Syph 1948; 32: 1-18.

17. Norris SJ, Miller JN, Sykes JA, Fitzgerald TJ. Influence of oxygen tension, sulfhydryl compounds, and serum on the motility and virulence of Treponema pallidum (Nichols strain) in a cell-free system. Infect Immun 1978; 22:689-97.

18. Mortensen $\mathbf{E}$. The nitroprusside method for the determination of reduced glutathione. Scand J Clin Lab Invest 1964; 1:87-97.

19. Cleland WW. Dithiothreitol, a new protective reagent for $\mathrm{SH}$ groups. Biochem 1964;3:480-2. 
20. Eldjarn L. Some biochemical effects of S-containing protective agents and the development of suitable SH/SS systems for the in vitro studies of such effects. Prog Biochem Pharmacol 1965; 1: 173-85

21. Jellum $\mathbf{E}$. The prevention of thio autoxidation in biological systems by means of thiolated sephadex. Acta Chem Scand 1964; 18: 1887-95.

22. Jocelyn PC. Biochemistry of the SH Group. New York: Academic Press, 1972.

23. Trowell OA. Cells and tissues in culture. In: Willmer EM, ed. Methods, Biology, and Physiology, vol 3. New York: Academic Press, 1963:64-149.
24. Cox CD, Barber MK. Oxygen uptake by Treponema pallidum. Infect Immun 1974; 10: 123-7.

25. Baseman JB, Nichols JC, Hayes NS. Virulent Treponema pallidum: aerobe or anaerobe? Infect Immun 1976; 13:704-11.

26. Horn RS, Haugaard N. Inhibition of carbohydrate metabolism by oxygen and $\mathrm{N}$-ethylmaleimide in rat heart homogenates. $J$ Biol Chem 1966;241:3078-82.

27. Morris JG. The physiology of obligate anaerobiosis. $A d v$ Microb Physiol 1975; 12:169-246.

28. Guzman-Barron ES. Oxidation of some oxidation-reduction systems by oxygen at high pressures. Arch Biochem Biophys 1955; 59:502-10. 